American Journal of Animal and Veterinary Sciences 6 (1): 35-39, 2011

ISSN 1557-4555

(C) 2011 Science Publications

\title{
Utilization of Eco-Feed Containing Mugwort Microorganism Compounds as a Feed Ingredient Source for Layer Hens
}

\author{
${ }^{1}$ Jassada Ruttanavut, ${ }^{1}$ Koh-en Yamauchi and ${ }^{2}$ Narin Thongwittaya \\ ${ }^{1}$ Department of Applied Biological Science, Laboratory of Animal Science, \\ Faculty of Agriculture, Kagawa University, Miki-cho, Kagawa-ken, Japan \\ ${ }^{2}$ Faculty of Animal Science and Technology, \\ Maejo University, Chiang Mai, Thailand
}

\begin{abstract}
Problem statement: Due to price hikes in feed, several strategies should be sought to reduce feeding costs. At the same time, there has been a considerable increase in environmental pollution from food waste. If food waste could be transferred into poultry diets, this would solve a great problem, helping poultry producers to reduce feeding costs, while reducing environmental problems arising from the disposal of food waste. The present study was performed to evaluate the possibility that Eco-feed (feed produced from recycled food waste) can be used as a feed ingredient source for layer hens. Approach: To promote the quality of conventional Eco-feed, it was sunk into Japanese Mugwort Silage Juice (JMSJ) including microorganism compounds and combined with a compound of microorganisms derived from JMSJ, resulting in Eco-feed Containing Mugwort microorganism compounds (ECM). Thirty-two 56-wk-old White Leghorn hens were divided into 4 groups of 8 birds each. They were fed 0 (control), 10, 20 or 30\% dietary ECM for 12 weeks. Results: Compared with the control, although the chickens in all the experimental groups consumed less feed $(\mathrm{p}<0.001)$, production performance in the 10 and $20 \%$ ECM groups did not decrease. None of the experimental groups were affected in terms of egg weight, shell strength, shell weight, shell thickness, albumen height, albumen weight, yolk weight, yolk color or Haugh unit. Conclusion: These results indicate that ECM can be a useful feed ingredient in commercial diets for laying hens at levels up to $20 \%$.
\end{abstract}

Key words: Recycled food waste, laying performance, egg quality, mugwort microorganisms, ingredient source, microorganism, eco-feed, Japanese Mugwort Silage Juice (JMSJ), dietary probiotics, pathogen inhibition, eco-feed containing mugwort

\section{INTRODUCTION}

In a big city, increasing much recycled food waste is large difficult problems. On the other hand, a potentially new feed ingredient for layer hens that might reduce feeding costs could be derived from the large amounts of food waste, food remnants or out-ofdate food from restaurants, supermarkets and convenience stores that are currently incinerated, buried, or used as a fertilizer source (compost) in big cities. In Japan, animal feed produced from the byproducts of the food processing industry and from food waste is referred as Eco-feed (a portmanteau of "eco" from ecology and economy and "feed"). Feeding Eco-feed to livestock is not a recent innovation. It has been practiced throughout the world and is often concentrated around metropolitan centers. Effective use of Eco-feed has been reported in pigs (Kjos et al., 2000) and chickens.

The beneficial effects of dietary probiotics are well known in poultry production. Recently, the beneficial effects of probiotics on growth performance (Saffar and Khajali, 2010), intestinal histology (Khambualai et al., 2010), nutrient digestibility (Mountzouris et al., 2010), modulation of intestinal microflora ( $\mathrm{Yu}$ et al., 2008) and pathogen inhibition (Higgins et al., 2008) have been reported in chickens. In a previous study, we reported increased body weight in broilers after feeding dried fermented ginger made from ginger and Japanese Mugwort Silage Juice (JMSJ) (Incharoen et al., 2010). The latter JMSJ included a mix of microorganisms such as lactic acid bacteria, yeast, photosynthetic bacteria, hyper-thermal bacteria, Actinomycetes, Aspergillus and Bacillus subtilis. To obtain a fundamental data whether

Corresponding Author: Koh-en Yamauchi, Department of Applied Biological Science, Laboratory of Animal Science, Faculty of Agriculture, Kagawa University, Miki-cho, Kagawa-ken, 761-0795, Japan Tel/Fax: +81-87-891-3053 
American J. Animal \& Vet. Sci., 6 (1): 35-39, 2011

or not Eco-feed can become the feed ingredient source, we tried to develop a new Eco-feed permeated with a compound of microorganisms by immersing Eco-feed into JMSJ. In this study, dietary Eco-feed containing mugwort microorganism compounds (ECM) was fed to layer hens and production performance and egg quality were measured.

\section{MATERIALS AND METHODS}

Eco-feed preparation: The ECM (Table 1) was produced by the company (Public Co., Ltd, Kagawa, Japan) as follows. Food remnants such as bread $(13.1 \%)$, noodles $(13.8 \%)$, fruit $(17.3 \%)$, vegetables $(7.2 \%)$, rice $(5.6 \%)$, meat $(7.5 \%)$, fish $(6.5 \%)$ and other mixed foods $(29 \%)$ were collected from restaurants, convenience stores and supermarkets in the Kagawa prefecture. From these collected food remnants, impurities such as plastic, metal, study and animal bones were removed manually. Per day, $300 \mathrm{~kg}$ of these Eco-feed sources were separately placed into three mini-containers (holding up to 400 liters). These minicontainers were filled with JMSJ until all of the Ecofeed sources were submerged. After two days, the JMSJ was drained from the mini-containers. The Eco-feed sources, now saturated with JMSJ, were then placed into a fermentation drying machine (Jetter type C, Wing Farm Co., Ltd, Hiroshima, Japan), in which the contents revolved at $70^{\circ} \mathrm{C}$ for $24 \mathrm{~h}$. and taken out and cooled.

The birds and the design of the experiment: The protocol of this study was approved by the Animal Care and Use Committee for Kagawa University and birds were handled according to the human care guidelines provided by Kagawa University. Fifty two-wk-old Single Comb White Leghorn hens (Gallus gallus domesticus; Julia strain) were reared in individual layer cages in a completely randomized design at a conventional ambient temperature. Light was provided for $16 \mathrm{~h}$ (from 6:00-22:00) each day. The hens were fed ad libitum with a conventional layer mash diet for a 4wk-period as an adaptation period to environment, during which, daily egg production and egg weight were recorded. Water was continuously available from nipple drinkers.

At 56-wk-old, 32 birds were divided into four dietary treatment groups based on a similar mean body weight and egg production level, with 8 birds in each group. A conventional layer mash diet (Table 2, Nippon Formula Feed MFG. Co., Ltd, Kanagawa, Japan) was
Table 1: Chemical analysis of Eco-feed containing mugwort microorganism compounds ${ }^{1}$

\begin{tabular}{lr}
\hline Item & Percent \\
\hline Dry matter & 82.10 \\
Crude protein & 15.78 \\
Gross energy $\left(\mathrm{kcal} \mathrm{kg}^{-1}\right)$ & 4012.00 \\
Crude fiber & 2.01 \\
Crude fat & 7.96 \\
Crude ash & 3.94 \\
Calcium & 0.12 \\
Phosphorus & 0.23 \\
\hline${ }^{1}$ Values are expressed on an as-fed basis. Each value is an average of \\
analyses done on two samples
\end{tabular}

provided as basal diet. The basal diet was replaced with $0,10,20$ or $30 \%$ ECM for a total of four treatments. The hens were given ad libitum access to water and their experimental diets for 12 weeks. Performance was determined every 4 weeks by measuring feed intake, feed efficiency (a ratio of egg weight to feed intake) and egg production. Body weight was measured at the beginning and at the end of the experiment. Egg quality was estimated by measuring the egg weight, shell strength, shell weight, shell thickness, albumen height, albumen weight, yolk weight, yolk color and the Haugh unit of each egg obtained on the final day of each of the four weeks. The shell strength of uncracked eggs was measured with an FHK testing machine (Fujihara Co., Ltd, Tokyo, Japan) and was recorded in maximum force $\left.(\mathrm{kg} \mathrm{cm})^{-2}\right)$ required to crack the shell surface. The albumen height was measured using a micrometer. The pigmentation of the egg yolk was measured visually using the Roche Yolk Color Fan and colors were scored according to 15 sample colors ranging from 1 (the lightest) to 15 (the darkest). Haugh units (Olobatoke and Mulugeta, 2011) were calculated as Haugh unit = $100 \log \left(\mathrm{H}-1.7 \mathrm{~W}^{0.37}+7.6\right)$, where $\mathrm{H}$ is an observed albumen height in millimeters and $\mathrm{W}$ is an observed weight of the egg in grams.

Statistical analyses: All data collected were analyzed by One-Way Analysis Of Variance (ANOVA), supported by the Statistical Analysis System (SAS V. 9.2, SAS Institute, Cary, NC). Statistical significant difference at $\mathrm{p}<0.05$ levels due to treatments was separated by Duncan's multiple range tests.

\section{RESULTS}

Laying performance and egg quality: Table 3 shows feed intake, body weight and egg production in layer hens fed 0,10, 20 and 30\% dietary ECM. Compared to the control, all the experimental groups showed a 
American J. Animal \& Vet. Sci., 6 (1): 35-39, 2011

Table 2: Feed formulation and nutrient composition of dietary Eco-feed containing mugwort microorganism compounds (ECM)

\begin{tabular}{|c|c|c|c|c|}
\hline \multirow[b]{2}{*}{ Ingredients (percent) } & \multicolumn{4}{|c|}{ Dietary ECM (percent) } \\
\hline & 0 & 10 & 20 & 30 \\
\hline Maize & 61.00 & - & - & - \\
\hline Milo & 1.00 & - & - & - \\
\hline Soybean meal & 16.00 & - & - & - \\
\hline Rapeseed meal & 4.00 & - & - & - \\
\hline Gluten meal & 3.00 & - & - & - \\
\hline Fish meal & 3.00 & - & - & - \\
\hline Rice bran & 1.00 & - & - & - \\
\hline Animal fat & 1.30 & - & - & - \\
\hline Calcium carbonate & 8.57 & - & - & - \\
\hline Dicalcium phosphate & 0.40 & - & - & - \\
\hline Salt $\quad 1-1+2$ & 0.20 & - & - & - \\
\hline Paprika & 0.03 & - & - & - \\
\hline Concentrate mixture ${ }^{1}$ & 0.50 & - & - & - \\
\hline Total & 100.00 & - & - & - \\
\hline Basal diet & 100.00 & 90.00 & 80.00 & 70.00 \\
\hline ECM & 0.00 & 10.00 & 20.00 & 30.00 \\
\hline \multicolumn{5}{|l|}{ Calculated composition } \\
\hline Crude protein & 17.00 & 16.90 & 16.80 & 16.70 \\
\hline Metabolizable energy $\left(\mathrm{kcal} \mathrm{kg}^{-1}\right)$ & 2850.00 & 2580.00 & 2630.00 & 2680.00 \\
\hline Crude fat & 3.00 & 3.50 & 4.00 & 4.50 \\
\hline Crude fiber & 6.00 & 5.60 & 5.20 & 4.80 \\
\hline Crude ash & 14.00 & 13.00 & 12.00 & 11.00 \\
\hline Calcium & 3.10 & 2.80 & 2.50 & 2.20 \\
\hline Available phosphorus & 0.45 & 0.43 & 0.41 & 0.39 \\
\hline
\end{tabular}

Table 3: Effects of dietary Eco-feed containing mugwort microorganism compounds (ECM) on laying performance and egg quality of chickens from 56 to $68 \mathrm{wk}$ of age

\begin{tabular}{|c|c|c|c|c|c|c|}
\hline \multirow[b]{2}{*}{ Variables } & \multicolumn{6}{|c|}{ Dietary ECM (percent) } \\
\hline & 0 & 10 & 20 & 30 & SEM $^{1}$ & p-value \\
\hline Feed intake (FI; g) & $7223.00^{\mathrm{a}}$ & $6560.00^{b}$ & $6674.00^{\mathrm{b}}$ & $6903.00^{b}$ & 58.300 & 0.001 \\
\hline Initial body weight (g) & 1632.00 & 1596.00 & 1646.00 & 1591.00 & 27.200 & 0.483 \\
\hline Final body weight (g) & 1667.00 & 1642.00 & 1682.00 & 1646.00 & 19.900 & 0.391 \\
\hline Body weight gain (g) & 35.00 & 46.00 & 36.00 & 55.00 & 13.100 & 0.683 \\
\hline Total egg production (TEP; g) & 5056.00 & 5111.00 & 5055.00 & 4786.00 & 55.300 & 0.142 \\
\hline Feed efficiency (TEP/FI) & 0.70 & 0.78 & 0.75 & 0.69 & 0.011 & 0.058 \\
\hline Egg production (\%) & 92.40 & 90.60 & 91.40 & 90.60 & 0.680 & 0.782 \\
\hline Egg weight (g) & 65.10 & 67.40 & 65.50 & 62.90 & 0.650 & 0.106 \\
\hline Shell strength $(\mathrm{kg} / \mathrm{cm})$ & 3.70 & 3.80 & 4.10 & 4.10 & 0.100 & 0.656 \\
\hline Shell weight (g) & 7.10 & 7.70 & 7.40 & 7.10 & 0.080 & 0.075 \\
\hline Shell thickness (mm) & 0.36 & 0.37 & 0.36 & 0.36 & 0.004 & 0.393 \\
\hline Albumen height $(\mathrm{cm})$ & 0.92 & 0.96 & 0.95 & 0.92 & 0.010 & 0.302 \\
\hline Albumen weight (g) & 40.60 & 42.50 & 40.10 & 38.70 & 0.510 & 0.057 \\
\hline Yolk weight (g) & 17.40 & 17.30 & 17.90 & 17.10 & 0.280 & 0.749 \\
\hline Yolk color & 11.10 & 11.10 & 11.40 & 11.20 & 0.100 & 0.618 \\
\hline Haugh unit & 94.30 & 96.20 & 95.70 & 95.00 & 0.440 & 0.475 \\
\hline
\end{tabular}

${ }^{\mathrm{a}, \mathrm{b}}$ Means with different superscripts in the same row are significantly different. ${ }^{1}$ SEM: standard error of means $(\mathrm{n}=8$ replicates per treatment)

decrease in feed intake $(\mathrm{p}<0.001)$, but showed a similar value in body weight gain $(p=0.68)$ and no change in total egg production $(\mathrm{p}=0.14)$. Egg production, egg weight, shell strength, shell weight, shell thickness, albumen height, albumen weight, yolk weight, yolk color and Haugh unit measurements did not differ from the control.

\section{DISCUSSION}

Diets produced from the food waste industry have not become part of the mainstream animal feed industry and generally have not been marketable for the following reasons: raw food waste has not always been collected as a consistent quantity; it often has a high 
moisture content and its quality deteriorates quickly; it does not include a consistent nutritional level; it has a high production cost; and there may be zoonotic risks associated with feeding food waste (Sugiura et al., 2009). With increasing demand for meat, technical progress in processing treatments, conservation methods and distribution networks, as well as a heightened awareness of food recycling, ecology and economy, many kinds of Eco-feed products have been tried. In pigs, food waste from a student cafeteria was useful as a feed for growing and finishing pigs (Westendorf et al., 1998). Dehydrated restaurant food waste products, in which food wastes containing $75 \%$ water were blended with a dry feedstock (resulting in $40 \%$ water), had the potential to produce a nutritious feedstuff (Myer et al., 1999). In poultry, dietary fermented fish silage can be used as an effective, suitable and cheaper protein source for Japanese quail (Zynudheen et al., 2008). Eco-feed produced from high-protein $(22.2 \% \mathrm{CP})$ and high-lipid $(26.4 \% \mathrm{CF})$ food waste showed 92.4, 92.5 and $93.0 \%$ egg production at $0, \quad 10$ and $20 \%$ dietary levels, respectively, suggesting that Eco-feed could be useful for laying hens. These egg production results correspond with the present results: egg production was 92.4, 90.6, 91.4 and $90.6 \%$ at $0,10,20$ and $30 \%$ dietary levels, respectively, even with lower levels of $\mathrm{CP}$ $(15.8 \%)$ and CF $(8.0 \%)$.

The reason that the present lower $\mathrm{CP}$ and CF levels could obtain egg production results similar to highprotein and high-lipid food waste might be related to a mix of microorganisms derived from JMSJ because the incorporation of a mix of microorganisms derived from JMSJ in ginger powder was shown to elevate egg production (Incharoen and Yamauchi, 2009). Although the present egg production (percent) showed lower levels in the experimental groups than in the control, total egg production weight was better in the $10 \%$ dietary level group than in the control. This might be induced by higher egg weight values, which is the total of the shell weight, shell thickness, albumen weight and yolk weight. Besides, yolk color did not show a difference among the groups.

\section{CONCLUSION}

A similarity to maintained total egg production in the 10 and 20\% ECM groups suggest that ECM may be considered a useful feed ingredient for laying hens when supplemented at levels of up to $20 \%$ in a conventional diet.

\section{REFERENCES}

Higgins, S.E., J.P. Higgins, A.D. Wolfenden, S.N. Henderson and A. Torres-Rodriguez et al., 2008. Evaluation of a Lactobacillus-based probiotic culture for the reduction of Salmonella Enteritidis in neonatal broiler chicks. Poult. Sci., 87: 27-31. PMID: 18079446

Incharoen, T. and K. Yamauchi, 2009. Production performance, egg quality and intestinal histology in laying hens fed dietary dried fermented ginger. Int. J. Poult. Sci 8: 1078-1085.

Incharoen, T., K. Yamauchi and N. Thongwittaya, 2010. Intestinal villus histological alterations in broilers fed dietary dried fermented ginger. J. Anim. Physiol. Anim. Nutr., 94: e130-e137. PMID: 20546067

Khambualai, O., K. Yamauchi, J. Ruttanavut, T. Incharoen and J. Kashimura et al., 2010. Effect of sugar cane extract, commercial probiotic and their mixture on growth performance and intestinal histology in broiler chickens. Am. J. Anim. Vet. Sci., $\quad$ 5: $132-138 . \quad$ DOI: 10.3844/ajavsp.2010.132.138

Kjos, N.P., M. Overland, E.A. Bryhni and O. Sorheim, 2000. Food waste products in diets for growingfinishing pigs: effect on growth performance, carcass characteristics and meat quality. Acta Agric. Scand. A Anim. Sci., 50: 193-204. DOI: 10.1080/090647000750014322

Mountzouris, K.C., P. Tsitrsikos, I. Palamidi, A. Arvaniti and M. Mohnl et al., 2010. Effects of probiotic inclusion levels in broiler nutrition on growth performance, nutrient digestibility, plasma immunoglobulins, and cecal microflora composition. Poult. Sci., 89: 58-67. PMID: 20008803

Myer, R.O., J.H. Brendemuhl and D.D. Johnson, 1999. Evaluation of dehydrated restaurant food waste products as feedstuffs for finishing pigs. J. Anim. Sci., 77: 685-692. PMID: 10229365

Olobatoke, R.Y. and S.D. Mulugeta, 2011. Effect of dietary garlic powder on layer performance, fecal bacterial load, and egg quality. Br. Poult. Sci., 90: 665-670. PMID: 21325240

Saffar, A. and F. Khajali, 2010. Application of meal feeding and skip-a-day feeding with or without probiotics for broiler chickens grown at highaltitude to prevent ascites mortality. Am. J. Anim. Vet. Sci., 5: 13-19. DOI: 10.3844/ajavsp.2010.13.19

Sugiura, K., S. Yamatani, M. Watahara and T. Onodera, 2009. Ecofeed, animal feed produced from recycled food waste. Vet. Ital., 45: 397-404. PMID: 20391403 
Westendorf, M.L., Z.C. Dong and P.A. Schoknecht, 1998. Recycled cafeteria food waste as a feed for swine: nutrient content digestibility, growth, and meat quality. J. Anim. Sci., 76: 2976-2983. PMID: 9928600

Yu, B., J.R. Liu, F.S. Hsiao and P.W.S. Chiou, 2008. Evaluation of Lactobacillus reuteri $\mathrm{Pg} 4$ strain expressing heterologous $\beta$-glucanase as a probiotic in poultry diets based on barley. Anim. Feed Sci. Technol., 141: 82-91.
Zynudheen, A.A., R. Anandan and K.G.R. Nair, 2008. Effect of dietary supplementation of fermented fish silage on egg production in Japanese quail (Coturnix coromandelica). Afr. J. Agric. Res., 3: 379-383. 